\title{
ENDODONTIC PREVENTIVE CONSIDERATION IN PULP AND PERIAPICAL TRAUMATISM IN FIXED FINAL RESTORATION (A CLINICAL REPORT)
}

Dennis $^{1}$

${ }^{1}$ Faculty of Dentistry, Universitas Sumatera Utara, Padang Bulan, Medan, Indonesia.

HOW TO CITE THIS ARTICLE: Dennis. Endodontic preventive consideration in pulp and periapical traumatism in fixed final restoration (a clinical report). J. Evolution Med. Dent. Sci. 2017;6(51):3933-3935, DOI: 10.14260/Jemds/2017/850

\section{PRESENTATION OF CASE}

A 56-year-old man was referred to the Department of Conservative Dentistry, Faculty of Dentistry, University of Sumatera Utara with main complaint of discomfort on chewing or percussion and palpation in his left canine. The patient had a PFM fixed bridge from 11 to 23 on his anterior side and he reported that the bridge was made a few years ago. Radiographic evaluation revealed that there was radiolucent periapical involvement, widening of periodontal ligament space and disruption of the lamina dura. Clinical finding was sinus tract that release the suppurative pressure (Figure 1).

\section{DIFFERENTIAL DIAGNOSIS}

Differential diagnosis of the case was pulp necrosis, apical periodontitis, periapical abscess and gingival abscess.

\section{CLINICAL DIAGNOSIS}

Clinical diagnosis of the tooth was symptomatic periapical abscess.

\section{PATHOLOGICAL DISCUSSION}

The infection from the necrotic pulp in the root canal system formed tough biofilm as the defence and virulence system of mixed flora. Bacteria and their by-products infected all root canal system and invaded periapical area. The infection in the periapical area caused suppurative mechanism and created sinus tract to reduce the periradicular pressure.

\section{DISCUSSION OF MANAGEMENT}

On first visit, the tooth was trephinated and pus drainage was performed in order to relieve the intradental pressure. Root canal was instrumented to completion using SS K-file with step-back system started from size \#25 and finished with size \#55. Irrigation was performed with Sodium hypochlorite $5.25 \%$ and EDTA as chelating agent. The canal was dried and an intracanal inter-appointment dressing with pure calcium hydroxide powder mixture and glycerin was placed. Root canal therapy was applied as treatment for this case.

\section{Financial or Other, Competing Interest: None.}

Submission 10-05-2017, Peer Review 06-06-2017,

Acceptance 09-06-2017, Published 24-06-2017.

Corresponding Author:

Dr. Dennis,

JL. Alumni No. 2,

Campus USU, Medan 20155,

Indonesia.

E-mail:dennis_dionisius@yahoo.co.uk

DOI: $10.14260 /$ jemds $/ 2017 / 850$

\section{(c) $(\mathrm{i})($}



Figure 1. Traumatised Tooth with Periapical Radiolucency

Two weeks later, \#40 gutta-percha cone was applied as master apical cone. The radiographic view showed there was an improvement of periapical radiolucency. Patient felt no discomfort feeling and no clinical symptoms was found (Figure 2).

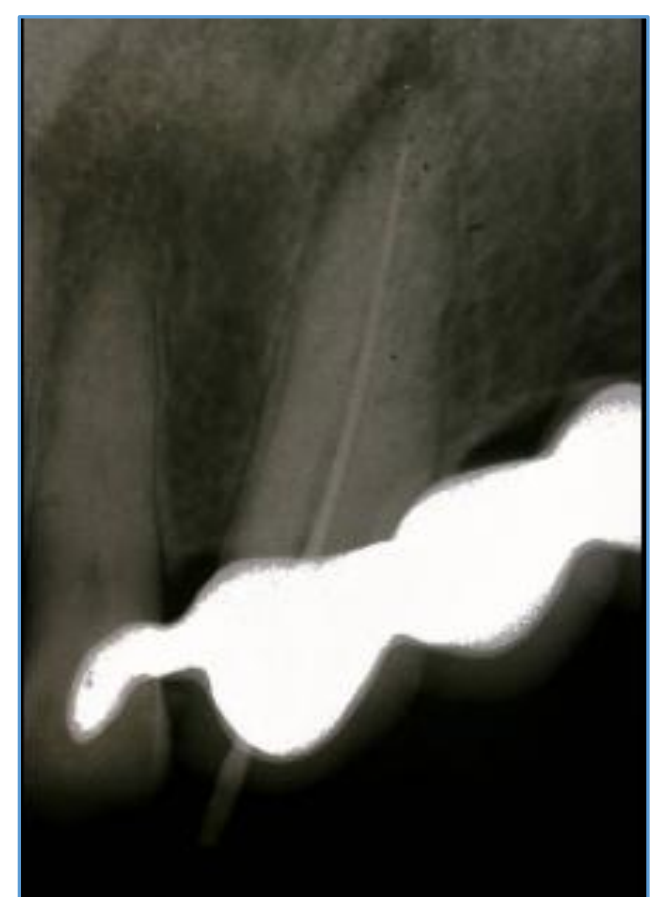

Figure 2. MAC with Gutta-Percha Cone 
A week later, root canal was then dried and filled with gutta percha and endomethasone sealer by using cold lateral condensation technique. The orifice was then sealed with GIC as lining material. Radiographic view revealed that there was diminution of the periapical radiolucency (Figure 3).

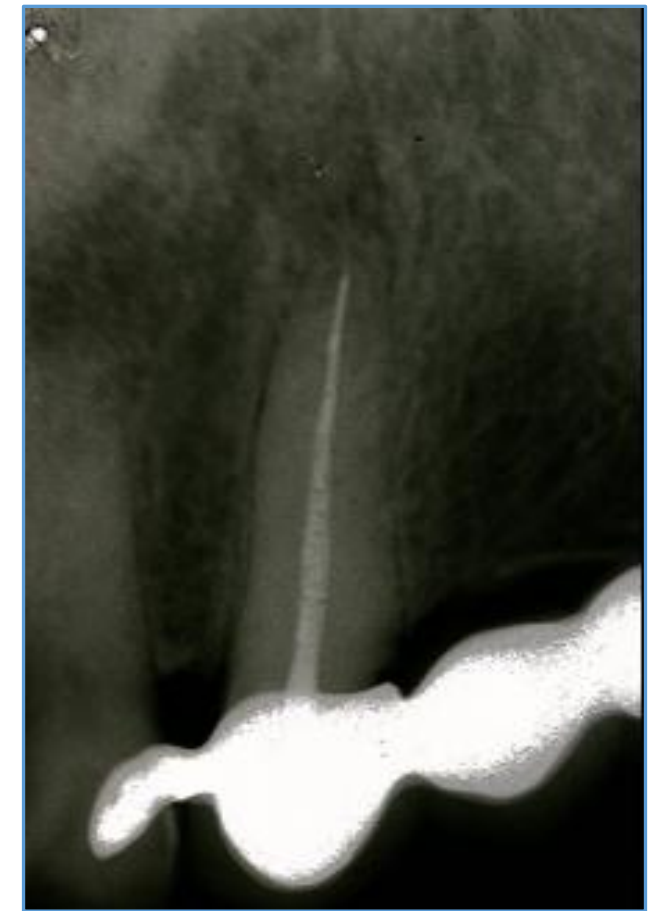

Figure 3. Filled Root Canal

In the fourth visit the filled root canal was observed with no clinical symptoms, no tenderness to percussion and palpation. Patient had no discomfort feeling. Final restoration was accomplished with composite resin filling by using silane agent as intermediate material between the PFM bridge and the adhesive material (Figure 4).

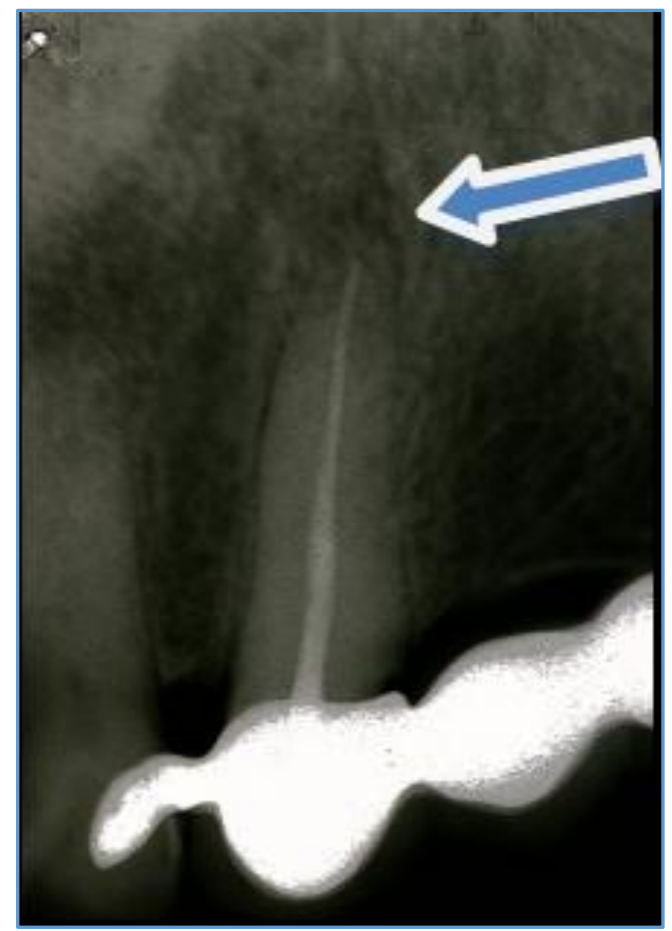

Figure 4. Diminution of Periapical Radiolucency

\section{FINAL DIAGNOSIS}

Final diagnosis was acute periapical abscess.

Pulp necrosis may develop when the abutment teeth are prepared to dentin-pulp complex disturbance and will undergo exudative process to be periapical abscess. ${ }^{1-4}$ The thickness of remaining dentin is proportional to the possibility of the microbial invasion and inflammation. In other words, the thinner the remaining dentin thickness the easier for the microbial invasion and the inflammation to take place. In this case the defense mechanism of the pulp was weakening, because the preparation of abutment did not consider the totality of pulp dentin complex. In addition, functional stress during mastication would cause the weakened pulpal defense. Inflammation process will begin and it will lead to pulp necrosis if the teeth are left untreated. Inflammation involves inflammatory cells, such as macrophage and lymphocyte which in turn will produce inflammatory mediators such as prostaglandins $\left(\mathrm{PGD}_{2}, \mathrm{PGE}_{1}\right.$, $\mathrm{PGE}_{2}, \mathrm{PGF}_{2}, \mathrm{PGI}_{2}$ ), cytokines (IL, TNF, IFN), leukotrienes and it will also affect the pain sensory nerve to produce several neuropeptides such as substance P, CGRP and NKA cells. ${ }^{5}$ These inflammatory mediators will cause bone resorption, pain, vasodilation, increased vascular permeability and neurovascular disorder.6-10 Therefore, a primary endodontic lesion draining through the attachment apparatus should be treated initially by endodontic therapy (Trephination). It was performed for pain relief by reducing intrapulpal pressure once the periapical abscess occurred. This opening established a pathway for drainage of the inflammatory exudates. ${ }^{7,11}$ In this case, calcium hydroxide was used as the intracanal inter-appointment dressing to disinfect the root canal system further and to evaluate the improvement of the surrounding tissues at the following appointment, at which time it was decided to fill the root canal. Osteogenesis was expected, so that healing of lesion and bone would occur. Though calcium hydroxide was applied only once; however, healing could already be seen through radiography in the second visit. It implied that root canal debridement and bacteria elimination held a very vital role in tissue repair as well as bone healing. ${ }^{11-12}$

In conclusion remaining dentin thickness must be an important consideration, because it plays a very important role during abutment tooth preparation for final partial denture such as bridge work and crown. The thickness will determine the possibility of inflammation and bacterial infection through the dentin tubules. Endodontic treatment must be performed in inflamed or necrotic abutment teeth under a bridge and successful healing can be achieved by performing adequate root canal treatment with great emphasis on disinfection and sealing of the root canal system. Intentional endodontic may be considered as a treatment option in preparing an abutment tooth for fixed partial denture.

\section{REFERENCES}

[1] Manappallil JJ. Classification system for conventional crown and fixed partial denture failures. J Prosthet Dent 2008;99(4):293-8.

[2] Pashley D. Pulpodentin complex. In: Hargreaves KM, Goodies HE. eds. Seltzer and Bender's dental pulp. Chicago: Quintessence Publishing Co, Inc., 2002:63-93. 
[3] Kelleher M, Tiernan J. Crown and bridge restoration. Clinical Risk 2004;10:60-4.

[4] Didilescu A, Iliescu R, Rusu D, et al. Current concepts on the relationship between pulpal and periodontal disease. TMJ 2008;58(1-2):98-103.

[5] Trowbridge HO, Emling RC. Inflammation: a review of the process. $4^{\text {th }}$ edn. Quintessence Publishing Co, Inc., 1997:19-40.

[6] Reit C, Petersson K, Molven O. Diagnosis of pulpal and periapical disease. In: Bergenholtz G, HorstedBindslev P, Reit C. eds. Textbook of endodontology. Blackwell Publishing Ltd., 2003:9-18.

[7] Vera J, Trope M, Barnett F, et al. Endodontic management of the endodontic-periodontal lesion. Endodontic Practice 2006:40-4.
[8] Rupf S, Kannengieber S, Merte K, et al. Comparison of profiles of key periodontal pathogens in periodontium and endodontium. Endodod Dent Traumatol 2000;16(6):269-75.

[9] Siqueira JF. Endodontic infections: concepts, paradigms and perspective. Oral Surg Oral Med Oral Pathol Oral Radiol Endod 2002;94(3):281-93.

[10] Matsuo T, Shirakami T, Ozaki K, et al. An immunohistological study of the localization of bacteria invading root pulpal walls of teeth with periapical lesions. J Endod 2003;29(3):194-200.

[11] Walker MR. The pathogenesis and treatment of endoperio lesion. CPD Dentistry 2001;2(3):91-5.

[12] Carrotte P. Endodontics: part 9 Calcium hydroxide, root resorption, endo-perio lesions. British Dental Journal 2004;197(12):735-43. 